\title{
Artificial shading promotes growth of taro plants ${ }^{1}$
}

\author{
Ancélio Ricardo de Oliveira Gondim², Mário Puiatti ${ }^{3}$, Fernando Luiz Finger ${ }^{3}$, Paulo Roberto Cecon ${ }^{4}$
}

\section{ABSTRACT}

Taro (Colocasia esculenta) is a plant with a long crop cycle, what hinders its cultivation in properties with area limitations. The association of crops is an option for this kind of situation. However, in order to plan the cultivation using the intercropping system, it is important to define the tolerance levels of the taro plants and the period of highest sensibility to shading. This study aimed to evaluate the behavior of the 'Japanese' taro crop, regarding growth, cultivated under levels and periods of artificial shading. A split-plot randomized block design, with 13 treatments and four replications, was used. The plots consisted of four shading levels (control = full sun, $18 \%, 30 \%$ and $50 \%$ of shade), maintained throughout the cycle or during three months, in three periods (initial $=0-3$ months; intermediate $=3-6$ months; final $=6-9$ months $)$. The subplot was composed of eight plant samples $(60,90,120$, $150,180,210,240$ and 270 days after planting). The shading levels increased the total and specific leaf area, leaf area and mass ratios and dry mass partition. Thus, the taro plants showed the capacity to make leaf adjustments to suit changes in light intensity. The shading intensity of $18 \%$, during the whole cycle or in any of the periods studied, provides a high expansion of the leaf area.

KEYWORDS: Colocasia esculenta; light restriction; growth analysis.

\section{INTRODUCTION}

Plant growth reflects the adaptation to radiation conditions in the environment. Growth characteristics are generally used to infer about the tolerance of species to light availability (Teixeira et al. 2015). Luminosity is one of the most important determinants of the photosynthetic plant productivity (Cavatte et al. 2009), and a low light intensity

\section{RESUMO}

Sombreamento artificial

promove o crescimento de plantas de taro

O taro (Colocasia esculenta) apresenta ciclo cultural longo, característica que dificulta o seu cultivo em propriedades com limitação de área. A associação de culturas é uma opção para situações dessa natureza. Todavia, é de fundamental importância, para se planejar o cultivo no sistema de consórcio, definir o nível de tolerância das plantas de taro e a época de maior sensibilidade ao sombreamento. Objetivou-se avaliar o comportamento do taro 'Japonês', quanto ao crescimento, cultivado sob níveis e períodos de sombreamento artificial. Utilizou-se delineamento experimental em blocos casualizados, com parcelas subdivididas no tempo, 13 tratamentos e quatro repetições. As parcelas consistiram de quatro níveis de sombreamento (controle $=$ pleno sol, $18 \%, 30 \%$ e $50 \%$ de sombra), mantidos durante todo o ciclo ou durante três meses, em três períodos (inicial $=0-3$ meses; intermediário $=3-6$ meses; final $=$ 6-9 meses). A subparcela foi composta por oito coletas de plantas $(60,90,120,150,180,210,240$ e 270 dias após o plantio). Os níveis de sombreamento aumentaram a área foliar total e específica, as razões de área e massa foliar e a partição de massa seca. Assim, as plantas de taro apresentaram a capacidade de fazer ajustes foliares para se adequarem a mudanças na intensidade luminosa. A intensidade de sombreamento de $18 \%$, durante o ciclo todo ou em qualquer dos períodos, proporciona elevada expansão da área foliar.

PALAVRAS-CHAVE: Colocasia esculenta; restrição de luz; análise de crescimento.

results in alterations of morphology, foliar anatomy, chloroplast ultrastructure, total exportation of assimilates and distribution patterns of assimilates (Bezerra et al. 2009), besides promoting the quality of seedlings and guaranteeing a better survival rate in the field.

The vegetative growth of taro (Colocasia esculenta) is initially very slow, reaching a peak between four and six months of the cycle, with a

1. Manuscript received in Feb./2018 and accepted for publication in May/2018 (http://dx.doi.org/10.1590/1983-40632018v4851355). 2. Universidade Federal de Campina Grande, Unidade Acadêmica de Ciências Agrárias, Pombal, PB, Brasil. E-mail: anceliogondim@hotmail.com.

3. Universidade Federal de Viçosa, Departamento de Fitotecnia, Viçosa, MG, Brasil.E-mails: mpuiatti@ufv.br, ffinger@ufv.br. 4. Universidade Federal de Viçosa, Departamento de Informática, Viçosa, MG, Brasil. E-mail: cecon@ufv.br. 
subsequent decline, characterized by a reduction in the number of leaves, leaf area, petiole length and plant height (Gondim et al. 2007). In the next phase, an inverse process begins, in which the new leaves are smaller, with a reduced growth rate, which may be paralyzed. According to Vieira et al. (2014), the leaf area growth shows a gradual increase from 30 to 120 days, followed by a steady decline up to 150 days. The leaf area index is an important physiological attribute to estimate the yield of the species, which is associated with a more significant dry mass production and distribution of photoassimilates.

The distribution patterns of photoassimilates may change under low light conditions. Usually, there is a decrease in photoassimilates directed to the reserve organs and an increase to the meristematic regions (Monim et al. 2010). Gondim et al. (2007) verified a reduction in the biomass distribution of other organs than the tubers, during the first 60 days of the taro cycle, with the luminosity reduction. Oliveira et al. (2011) observed that conditions of marked light restriction (50\% and $75 \%$ of light restriction) induced an initial investment of 'Chinese' taro plants in shoot growth and in the expansion of the leaf area, in detriment of the root production, causing a delay in the formation of reserve structures and a reduction in the rhizomes productivity. Lenhard et al. (2013) also verified that plants grown under $70 \%$ of shading presented higher levels of total chlorophyll and leaf area and weight ratios.

Therefore, shading is expected to affect the growth of taro plants, and the definition of the tolerance level and season of higher sensitivity are of fundamental importance in planning their cultivation. With this knowledge and the phenology of the species to be used, it is possible to define the percentage of shading and the most appropriate season(s) for cultivating the plant. Thus, this study aimed to evaluate the effect of levels and periods of artificial shading on the growth of the 'Japanese' taro crop.

\section{MATERIAL AND METHODS}

The experiment was developed at the Universidade Federal de Viçosa - UFV (20\%45'S, $42^{\circ} 51^{\prime} \mathrm{W}$ and $652 \mathrm{~m}$ of altitude), from April 2005 to April 2006.

The experimental area presents a slight slope, and the soil is classified as a Cambic Red-Yellow
Argisol, with the following chemical characteristics: $\mathrm{pH}\left(\mathrm{H}_{2} \mathrm{O}\right)=5.7 ; \mathrm{H}+\mathrm{Al}=2.97 \mathrm{mg} \mathrm{dm}^{-3} ; \mathrm{P}=$ $41.9 \mathrm{mg} \mathrm{dm}^{-3} ; \mathrm{K}=81 \mathrm{mg} \mathrm{dm}^{-3} ; \mathrm{Ca}=2.8 \mathrm{cmol} \mathrm{dm}_{\mathrm{c}} \mathrm{d}^{-3}$; $\mathrm{Mg}=0.7 \mathrm{cmol} \mathrm{dm}^{-3} ;$ organic matter $=20.8 \mathrm{dag} \mathrm{kg}^{-1} ; \mathrm{Zn}=$ $5.1 \mathrm{mg} \mathrm{dm}^{-3} ; \mathrm{Fe}=38.5 \mathrm{mg} \mathrm{dm}^{-3} ; \mathrm{Mn}=32.7 \mathrm{mg} \mathrm{dm}^{-3}$; $\mathrm{Cu}=2.9 \mathrm{mg} \mathrm{dm}^{-3}$ and $\mathrm{B}=0.57 \mathrm{mg} \mathrm{dm}^{-3}$. The soil preparation consisted of plowing, harrowing and grooving, in rows spaced at $1.0 \mathrm{~m}$ and with $0.12 \mathrm{~m}$ of depth. The 'Japanese' taro plant (BGH 5925) rhizome, from the germplasm bank of the UFV, was used as seedling, with an average mass of $100 \mathrm{~g}$.

A split-plot design was used, consisting of 13 treatments, divided into four shading levels (control $=$ $0 \%, 18 \%, 30 \%$ and $50 \%$ ) and four periods for the treatments with shading (full time $=9$ months of shading; initial $=$ shading in the first three months; intermediate $=$ shading from the fourth to the sixth month; final $=$ shading from the seventh to the ninth month). The treatments were named as: Sun $(0 \%$ of shading); 18T, 30T and 50T (for full time of shading); 18I, 30I and 50I (for shading at the first 3 months); $18 \mathrm{M}, 30 \mathrm{M}$ and $50 \mathrm{M}$ (for shading at the intermediate 3 months); 18F, 30F and 50F (for shading at the last 3 months). Four replicates were used, and the treatments were distributed in randomized blocks. Samples were made at 60, 90, 120, 150, 180, 210, 240 and 270 days after planting (DAP), by collecting one plant per replicate.

The plot consisted of four rows ( $3.0 \mathrm{~m}$ long), with a distance of $1.0 \mathrm{~m}$ from each other, and the plants were spaced at $0.30 \mathrm{~m}$ apart, totaling 40 plants in an area of $12.0 \mathrm{~m}^{2}$. The central area was considered useful, except for $0.60 \mathrm{~m}$ of the extremities. The shading levels were obtained by Sombrite ${ }^{\circledR}$ meshes placed about $0.50 \mathrm{~m}$ above the canopy, elevated as the plants grew in height.

There was no addition of fertilizer or any kind of chemical control. A sprinkling irrigation system was used to complete $40 \mathrm{~mm}$ of water per week, which is considered a value suitable for the taro crop. The weeds were removed at 21, 59, 79, 114 and 199 days after planting.

During each evaluation period, the plants were harvested and separated into shoot (leaf = blade and petiole) and rhizome, and dried in a laboratory oven with forced ventilation at $60{ }^{\circ} \mathrm{C}$, for three days. The parameters analyzed were: leaf area $\left(\mathrm{cm}^{2}\right.$ plant $\left.{ }^{-1}\right)$, leaf area ratio $\left(\mathrm{cm}^{2} \mathrm{~g}^{-1}\right)$, specific leaf area $\left(\mathrm{cm}^{2} \mathrm{~g}^{-1}\right)$ and leaf mass ratio $\left(\mathrm{g} \mathrm{g}^{-1}\right)$. The leaf mass ratio was calculated by the ratio of leaf dry mass ( $\mathrm{g}$ ) to the total dry mass 
of the plant (g). The dry mass partition was obtained by the percentage of participation of the blade, petiole and rhizome dry mass from the total plant dry mass.

The mean, maximum and minimum temperatures were measured during the experiment, using a Term-Hygrometer (Brand Icel, model HT208), placed at the same height as the plant canopy in all treatments (Table 1).

To evaluate the differences among treatments, the variance analysis (Anova) was used, as well as regressions to fit the dependent variables (leaf area, leaf area ratio, specific leaf area and leaf mass ratio), as a function of time. The Anova was performed using the Sisvar 4.0 (Ferreira 2000) and the regressions using the Sigma Plot softwares.

\section{RESULTS AND DISCUSSION}

Shading decreased the mean, maximum and minimum air temperature. The reduction in temperature was proportional to the shading intensity, i.e., the shading percentage (Table 1). Shading promotes changes in the microclimate, thus reducing the air temperature and favoring leaf growth (Gondim et al. 2007). Besides directly affecting the water evaporation from the soil, these changes act on all the vital processes and plant growth.

The leaf area was similar among the shading levels, with the highest values at 90-210 DAP. After this period, the leaf area decreased until the end of the experiment. The highest leaf area occurred at $50 \%$ of shading, and then at $30 \%$, both with full time shading (50T and 30T treatments). The lowest leaf area was observed at full sun $(0 \%)$ and $18 \%$ of shading, during all the cycle (treatment 18T), mainly at the first 180 days (Figure 1a).

Shading promoted the expansion of the leaf blade of taro plants in most the treatments, with larger leaf area and specific leaf area (Table 2; Figures $1 \mathrm{a}$ and $1 \mathrm{~b}$ ) and lower fresh and dry mass (data not shown), in comparison to the control. The number of leaves did not increase with the increase in shading (data not shown). Similar results were found by Pereira et al. (2006) and Santos et al. (2015). The maximum leaf area was found at 90 and 120 DAP for all treatments. A similar behavior was observed for passion fruit, since the plant needs to enlarge the photosynthetic surface to maximize the light absorption (Silva et al. 2006).

Taro plants with $50 \%$ of shading had a higher leaf area during all the experimental time, showing that light restrictions stimulate the leaf expansion to increase the light absorption (Figure 1a). Similar results were observed by Oliveira et al. (2008), who found that taro plants cultivated at $75 \%$ of light restriction had a large leaf area.

The specific leaf area of the plants, during the crop cycle, had a similar behavior, independently of the shading levels, i.e., a quick increase up to 90 DAP, followed by a slight decline until the end of the cycle, except for the treatments 18I, 30I, 50I, 18F and $50 \mathrm{~F}$. A higher specific leaf area was observed under shading levels of $50 \%$ and $30 \%$, applied during all the experimental time, up to 150 days. The control

Table 1 . Monthly average of maximum, minimum and mean air temperature $\left({ }^{\circ} \mathrm{C}\right.$ ) at $0 \%$ (full sun), $18 \%, 30 \%$ and $50 \%$ of shading, using a shade cloth.

\begin{tabular}{|c|c|c|c|c|c|c|c|c|}
\hline \multirow{2}{*}{ Treatment } & \multicolumn{8}{|c|}{ Month } \\
\hline & $\mathrm{N}$ & $\mathrm{D}$ & $\mathrm{J}$ & $\mathrm{F}$ & $\mathrm{M}$ & $\mathrm{A}$ & $\mathrm{M}$ & $\mathrm{J}$ \\
\hline & \multicolumn{8}{|c|}{ Maximum } \\
\hline Full sun & 40.9 & 43.3 & 44.0 & 44.7 & 44.5 & 42.8 & 35.0 & 34.7 \\
\hline $18 \%$ & 40.1 & 41.0 & 41.5 & 42.0 & 41.9 & 40.8 & 34.0 & 33.5 \\
\hline $30 \%$ & 39.1 & 39.4 & 39.7 & 40.4 & 40.0 & 39.5 & 32.6 & 32.3 \\
\hline \multirow[t]{2}{*}{$50 \%$} & 37.6 & 37.9 & 38.2 & 38.7 & 38.5 & 38.3 & 31.7 & 31.6 \\
\hline & \multicolumn{8}{|c|}{ Minimum } \\
\hline Full sun & 16.7 & 18.5 & 19.5 & 19.2 & 18.7 & 17.7 & 16.9 & 12.8 \\
\hline $18 \%$ & 15.5 & 18.0 & 19.0 & 18.9 & 18.4 & 17.0 & 16.0 & 12.0 \\
\hline $30 \%$ & 14.7 & 17.5 & 18.5 & 18.3 & 18.0 & 16.3 & 15.5 & 11.5 \\
\hline \multirow[t]{2}{*}{$50 \%$} & 14.0 & 17.0 & 17.7 & 17.5 & 17.2 & 15.6 & 15.0 & 10.5 \\
\hline & \multicolumn{8}{|c|}{ Mean } \\
\hline Full sun & 28.8 & 30.9 & 31.8 & 32.0 & 31.6 & 30.3 & 26.0 & 23.8 \\
\hline $18 \%$ & 27.8 & 29.5 & 30.3 & 30.5 & 30.2 & 28.9 & 25.0 & 22.8 \\
\hline $30 \%$ & 26.9 & 28.5 & 29.1 & 29.4 & 29.0 & 27.9 & 24.1 & 21.9 \\
\hline $50 \%$ & 25.8 & 27.5 & 28.0 & 28.1 & 27.9 & 27.0 & 23.3 & 21.1 \\
\hline
\end{tabular}


treatment and shading at $18 \%$, applied during all the experiment, showed the lowest values for specific leaf area, mainly at the phase of higher vegetative growth (Figure 1b).

The results for specific leaf area (Table 2; Figure $1 b$ ) show that the leaf expansion occurred without a corresponding increase in dry leaf mass, as the shading level increased, with a maximum specific leaf area of $304.5 \mathrm{~cm}^{2} \mathrm{~g}^{-1}$, at 84 days, at $50 \%$ of shading throughout the cycle. Plants subjected to shading expand the leaf area and decrease the blade thickness (Radin et al. 2004). A similar behavior of increase in specific leaf area with the increase in shading was found by Barrella et al. (2011) and Mota et al. (2008), for carrot and grape crops, respectively.
The expantion of the specific leaf area in plants with $50 \%$ of shading suggests that the reduction of brightness affects the anatomical differences in the leaf (Gondim et al. 2008), what gives a competitive ability under conditions of low luminosity. In the full sun treatment, the plant presented a smaller specific leaf area and a lower leaf area ratio, a strategy that benefits plants under high light intensity, reducing the plant tissue exposure to the sun, water loss and auto-shading.

The results of fitted equations for the leaf area ratio are shown in Table 2. The leaf area ratio is the ratio between the leaf area (responsible for the interception of light energy and $\mathrm{CO}_{2}$ ) and total dry mass (result of the photosynthesis), and decreases
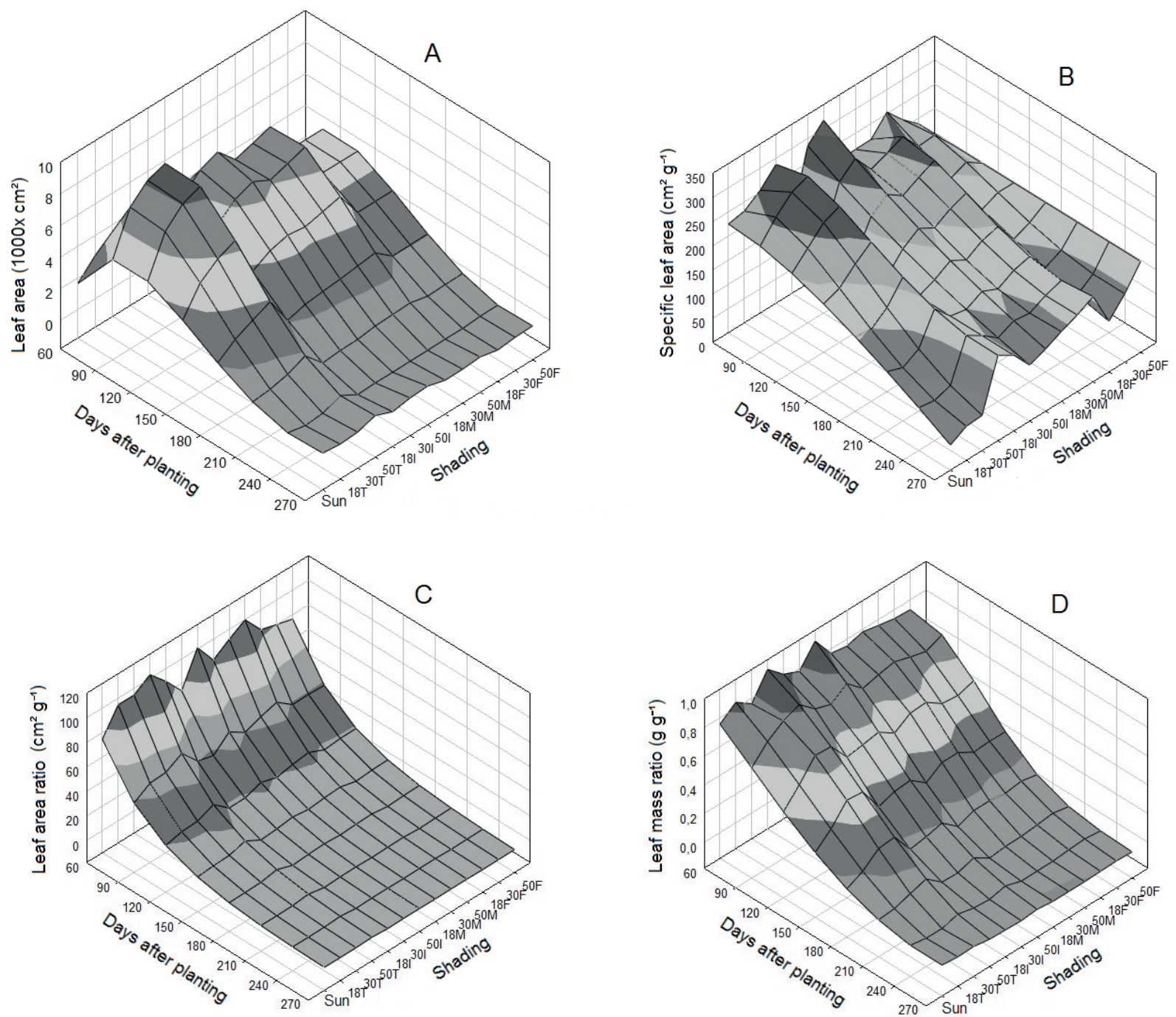

Figure 1. Estimates of leaf area (A), specific leaf area (B), leaf area ratio (C) and leaf mass (D) of 'Japanese' taro plants cultivated under levels [control (sun) and $18 \%, 30 \%$ and $50 \%$ ] and periods [full time (T), initial (I), intermediate (M) and final period of the cycle (F)] of artificial shading. 
Table 2. Equations for leaf area, specific leaf area, leaf area ratio and leaf mass ratio of 'Japanese' taro plants, as a function of the number of days after planting (x), cultivated at distinct shading levels and periods, and results for the coefficient of determination.

\begin{tabular}{|c|c|c|}
\hline Treatment & Leaf area & $\mathrm{R}^{2}$ \\
\hline Sun & $\hat{\mathrm{y}}=-87727.5+23103.4 * \mathrm{x}^{0.5}-1862.3 * \mathrm{x}+47.6^{* *} \mathrm{x}^{1.5}$ & 0.9829 \\
\hline $18 \mathrm{~T}$ & $\hat{\mathrm{y}}=-140690.0+37272.1 * * \mathrm{x}^{0.5}-3023.8^{* *} \mathrm{x}+77.8^{* *} \mathrm{x}^{1.5}$ & 0.9858 \\
\hline $30 \mathrm{~T}$ & $\hat{\mathrm{y}}=-162371.0+42866.9^{* *} \mathrm{x}^{0.5}-3467.6^{* *} \mathrm{x}+88.9^{* *} \mathrm{x}^{1.5}$ & 0.9910 \\
\hline $50 \mathrm{~T}$ & $\hat{\mathrm{y}}=-160558.0+42403.2 * * \mathrm{x}^{0.5}-3420.7 * * \mathrm{x}+87.5^{*} * \mathrm{x}^{1.5}$ & 0.9869 \\
\hline $18 \mathrm{I}$ & $\hat{y}=-103260.0+27896.8^{* *} x^{0.5}-2296.4^{* *} x+59.8^{* *} x^{1.5}$ & 0.9792 \\
\hline $30 \mathrm{I}$ & $\hat{\mathrm{y}}=-122734.0+33200.8 * * \mathrm{x}^{0.5}-2739.4 * * \mathrm{x}+71.5^{* *} \mathrm{x}^{1.5}$ & 0.9612 \\
\hline $50 \mathrm{I}$ & $\hat{y}=-134482.0+36320.4 * * x^{0.5}-2996.9 * * x+78.3 * * x^{1.5}$ & 0.9411 \\
\hline $18 \mathrm{M}$ & $\hat{\mathrm{y}}=-133517.0+34877.4^{* *} \mathrm{x}^{0.5}-2806.5^{* *} \mathrm{x}+71.8^{* *} \mathrm{x}^{1.5}$ & 0.9653 \\
\hline $30 \mathrm{M}$ & $\hat{y}=-142465.0+37179.6^{* *} x^{0.5}-2990.6^{* *} x+76.5^{* *} x^{1.5}$ & 0.9758 \\
\hline $50 \mathrm{M}$ & $\hat{\mathrm{y}}=-153526.0+40045.0^{* *} \mathrm{x}^{0.5}-3223.2^{* *} \mathrm{x}+82.5^{* *} \mathrm{x}^{1.5}$ & 0.9813 \\
\hline $18 \mathrm{~F}$ & $\hat{\mathrm{y}}=-89284.8+23480.1 * * \mathrm{x}^{0.5}-1889.3 * * \mathrm{x}+48.2 * * \mathrm{x}^{1.5}$ & 0.9813 \\
\hline $30 \mathrm{~F}$ & $\hat{\mathrm{y}}=-89126.3+23457.4 * * \mathrm{x}^{0.5}-1889.7 * * \mathrm{x}+48.3 * * \mathrm{x}^{1.5}$ & 0.9778 \\
\hline $50 \mathrm{~F}$ & $\hat{\mathrm{y}}=-89183.8+23478.3 * * \mathrm{x}^{0.5}-1892.2 * * \mathrm{x}+48.4 * * \mathrm{x}^{1.5}$ & 0.9786 \\
\hline Treatment & Specific leaf area & $\mathrm{R}^{2}$ \\
\hline Sun & $\hat{\mathrm{y}}=67.0+39.4^{\mathrm{ns}} \mathrm{x}^{0.5}-2.45^{*} \mathrm{x}$ & 0.9102 \\
\hline $18 \mathrm{~T}$ & $\hat{\mathrm{y}}=-1394.1+436.6 * \mathrm{x}^{0.5}-36.5 * \mathrm{x}+0.94 * * * \mathrm{x}^{1.5}$ & 0.9539 \\
\hline $30 \mathrm{~T}$ & $\hat{y}=-1521.4+470.2 * x^{0.5}-38.6 * x+0.97 * x^{1.5}$ & 0.9849 \\
\hline $50 \mathrm{~T}$ & $\hat{y}=-954.8+341.1 * x^{0.5}-29.4 * x+0.78 * x^{1.5}$ & 0.9564 \\
\hline $18 \mathrm{I}$ & $\hat{y}=156.48$ & - \\
\hline 30I & $\hat{y}=369.4 \exp \left(-0.0043^{*} x\right)$ & 0.8532 \\
\hline $50 \mathrm{I}$ & $\hat{y}=411.34 \exp (-0.0043 * x)$ & 0.8415 \\
\hline $18 \mathrm{M}$ & $\hat{y}=-994.2+326.7 * x^{0.5}-27.7 * x+0.73 * x^{1.5}$ & 0.9486 \\
\hline $30 \mathrm{M}$ & $\hat{y}=-1120.2+354.1^{*} x^{0.5}-29.3 * x+0.76^{*} x^{1.5}$ & 0.9232 \\
\hline $50 \mathrm{M}$ & $\hat{y}=-1549.2+467.1 * x^{0.5}-38.7 * x+1.02 * x^{1.5}$ & 0.9122 \\
\hline $18 \mathrm{~F}$ & $\hat{y}=325.98 \exp (-0.0042 * x)$ & 0.8809 \\
\hline $30 \mathrm{~F}$ & $\hat{\mathrm{y}}=-591.4+223.3 * * * \mathrm{x}^{0.5}-19.3 * * * \mathrm{x}+0.51 * * * \mathrm{x}^{1.5}$ & 0.8998 \\
\hline $50 \mathrm{~F}$ & $\hat{y}=-188.33$ & - \\
\hline Treatment & Leaf area ratio & $\mathrm{R}^{2}$ \\
\hline Sun & $\hat{\mathrm{y}}=277.4 \exp (-0.022 * x)$ & 0.9854 \\
\hline $18 \mathrm{~T}$ & $\hat{y}=387.6 \exp \left(-0.023^{*} x\right)$ & 0.9921 \\
\hline $30 \mathrm{~T}$ & $\hat{y}=375.9 \exp (-0.023 * x)$ & 0.9811 \\
\hline $50 \mathrm{~T}$ & $\hat{y}=363.5 \exp (-0.021 * x)$ & 0.9812 \\
\hline $18 \mathrm{I}$ & $\hat{\mathrm{y}}=434.8 \exp \left(-0.026^{*} \mathrm{x}\right)$ & 0.9825 \\
\hline $30 \mathrm{I}$ & $\hat{y}=292.0 \exp \left(-0.023^{*} x\right)$ & 0.9893 \\
\hline $50 \mathrm{I}$ & $\hat{y}=439.5 \exp \left(-0.024^{*} x\right)$ & 0.9904 \\
\hline $18 \mathrm{M}$ & $\hat{y}=356.7 \exp (-0.024 * x)$ & 0.9693 \\
\hline $30 \mathrm{M}$ & $\hat{y}=385.5 \exp (-0.024 * x)$ & 0.9671 \\
\hline $50 \mathrm{M}$ & $\hat{y}=421.5 \exp (-0.024 * x)$ & 0.9499 \\
\hline $18 \mathrm{~F}$ & $\hat{y}=393.7 \exp \left(-0.026^{*} x\right)$ & 0.9807 \\
\hline $30 \mathrm{~F}$ & $\hat{\mathrm{y}}=335.2 \exp (-0.024 * x)$ & 0.9769 \\
\hline $50 \mathrm{~F}$ & $\hat{\mathrm{y}}=303.6 \exp (-0.023 * x)$ & 0.9789 \\
\hline Treatment & Leaf mass ratio & $\mathrm{R}^{2}$ \\
\hline Sun & $\hat{\mathrm{y}}=-0.12+0.390829 * * * \mathrm{x}^{0.5}-0.047 * \mathrm{x}+0.0014 * \mathrm{x}^{1.5}$ & 0.9962 \\
\hline $18 \mathrm{~T}$ & $\hat{\mathrm{y}}=0.95+0.0007^{\mathrm{ns}} \mathrm{x}-0.000049 * \mathrm{x}^{2}+0.00000013 * * \mathrm{x}^{3}$ & 0.9973 \\
\hline $30 \mathrm{~T}$ & $\hat{\mathrm{y}}=0.18+0.017 * x-0.0001 * \mathrm{x}^{2}+0.0000003 * \mathrm{x}^{3}$ & 0.9788 \\
\hline $50 \mathrm{~T}$ & $\hat{y}=0.92+0.0035^{\mathrm{ns}} \mathrm{x}-0.000064 * * * \mathrm{x}^{2}+0.00000014 * \mathrm{x}^{3}$ & 0.9919 \\
\hline $18 \mathrm{I}$ & $\hat{\mathrm{y}}=\exp \left(-0.48+0.011 * * x-0.00010^{*} \mathrm{x}^{2}\right)$ & 0.9870 \\
\hline $30 \mathrm{I}$ & $\hat{y}=\exp \left(-0.00019-0.0067^{\mathrm{ns}} x+0.000073 * x^{2}-0.00000049 * x^{3}\right)$ & 0.9815 \\
\hline $50 \mathrm{I}$ & $\hat{y}=\exp \left(0.000045+0.0015^{\mathrm{ns}} \mathrm{x}-0.000043^{\mathrm{ns}} \mathrm{x}^{2}-0.000000083^{*} \mathrm{x}^{3}\right)$ & 0.9782 \\
\hline $18 \mathrm{M}$ & $\hat{y}=\exp \left(-0.00021-0.0073^{n s} x+0.000087 * * * x^{2}-0.00000064 * x^{3}\right)$ & 0.9933 \\
\hline $30 \mathrm{M}$ & $\hat{y}=\exp \left(-0.00029-0.010^{\mathrm{ns}} \mathrm{x}+0.00013^{* * *} \mathrm{x}^{2}-0.00000076^{*} \mathrm{x}^{3}\right)$ & 0.9825 \\
\hline $50 \mathrm{M}$ & $\hat{y}=\exp \left(-0.00024-0.0084 * x+0.00011 * x^{2}-0.00000069 * x^{3}\right)$ & 0.9952 \\
\hline $18 \mathrm{~F}$ & $\hat{\mathrm{y}}=\exp \left(-0.66+0.013 * * \mathrm{x}-0.00011 * \mathrm{x}^{2}\right)$ & 0.9978 \\
\hline $30 \mathrm{~F}$ & $\hat{\mathrm{y}}=\exp \left(-0.56+0.010 * * \mathrm{x}-0.000097 * * \mathrm{x}^{2}\right)$ & 0.9984 \\
\hline $50 \mathrm{~F}$ & $\hat{\mathrm{y}}=\exp \left(-0.96+0.019 * * x-0.00014 * \mathrm{x}^{2}\right)$ & 0.9985 \\
\hline
\end{tabular}

*,**,*** and ns: significant at $1 \%, 5 \%$ and $10 \%$ and non-significant, respectively. Shading periods: full time (T), initial (I), intermediate (M) and at the final period of the cicle (F). 
with time. A decrease of leaf area ratio in time was observed, but high values of leaf area ratio were found in the treatments with higher shading, especially at the 50T treatment (Table 2; Figure 1c). Lower values were found at the full sun treatment, what indicates a reduction in the sun exposition, water loss and autoshading (Silva et al. 2006, Oliveira et al. 2014).

The leaf mass ratio, in treatments with shading, differed from the control up to 180 DAP. Up to the day 60 , only the treatments $18 \mathrm{~T}, 50 \mathrm{~T}, 18 \mathrm{I}$ and 50I differed from the control. At the day 90 , the mass ratio increased significantly in the treatments $18 \mathrm{~T}, 30 \mathrm{~T}$, 50T, 18I, 30I, 50I and 50M, concerning the control. At the day 120, the treatments with $18 \%, 30 \%$ and $50 \%$ of shading, in the periods of $0-270,0-90$ and 90-180 days, were higher than the control. At 150 days, the leaf mass ratio was higher than the control, for the treatments $18 \mathrm{I}, 30 \mathrm{~T}, 30 \mathrm{I}, 50 \mathrm{~T}, 50 \mathrm{I}$ and $50 \mathrm{M}$. At 180 days, the treatmets $30 \mathrm{~T}$ and 50T increased significantly, concerning the control (Figure 1d).

The leaf mass ratio is the ratio between the leaf and the plant dry mass, and expresses the dry mass fraction not exported from the leaves to the rest of the plant. A low leaf mass ratio indicates that more mass was directed to stems and roots than leaves, what may be advantageous for plants exposed to high shading levels, allowing a greater absorption of water and nutrients, due to the high root mass.
The leaf mass ratio decreased along the time (Table 2; Figure 1d), as occurred with the leaf area ratio and specific leaf area. This shows that, during the cycle, a lower mass fraction was retained in the leaves, due to the mass gain by subterranean structures (mother and son-rhizomes) and gradual shoot senescence (data not shown).

The plants subjected to shading at the period of 0-90 days showed burning signals of the upper leaves after the removal of the shading meshes. This occurred due to the sudden increase in the exposure to direct light (Gondim et al. 2007), since the mesh remotion occurred during the summer, with a high heat and solar radiation.

The treatments that received constant shading had a significant accumulation of dry mass at the rhizomes and decreased the accumulation of dry mass in the shoots. At 90 days, these organs accumulated $60 \%, 69 \%, 75 \%$ and $76 \%$ of the total dry mass in the control treatments (full sun), and $18 \%, 30 \%$ and $50 \%$ in the shading treatments (Figure 2). Up to the day 180, the mass partition decrease from the leaves and petioles and increase in the rhizomes. From 210 DAP, the sonrhizomes showed more than $50 \%$ of partition from the assimilates. However, only the $18 \%$ shading treatment continued to accumulate dry mass. At 270 days, the son-rhizomes showed a biomass

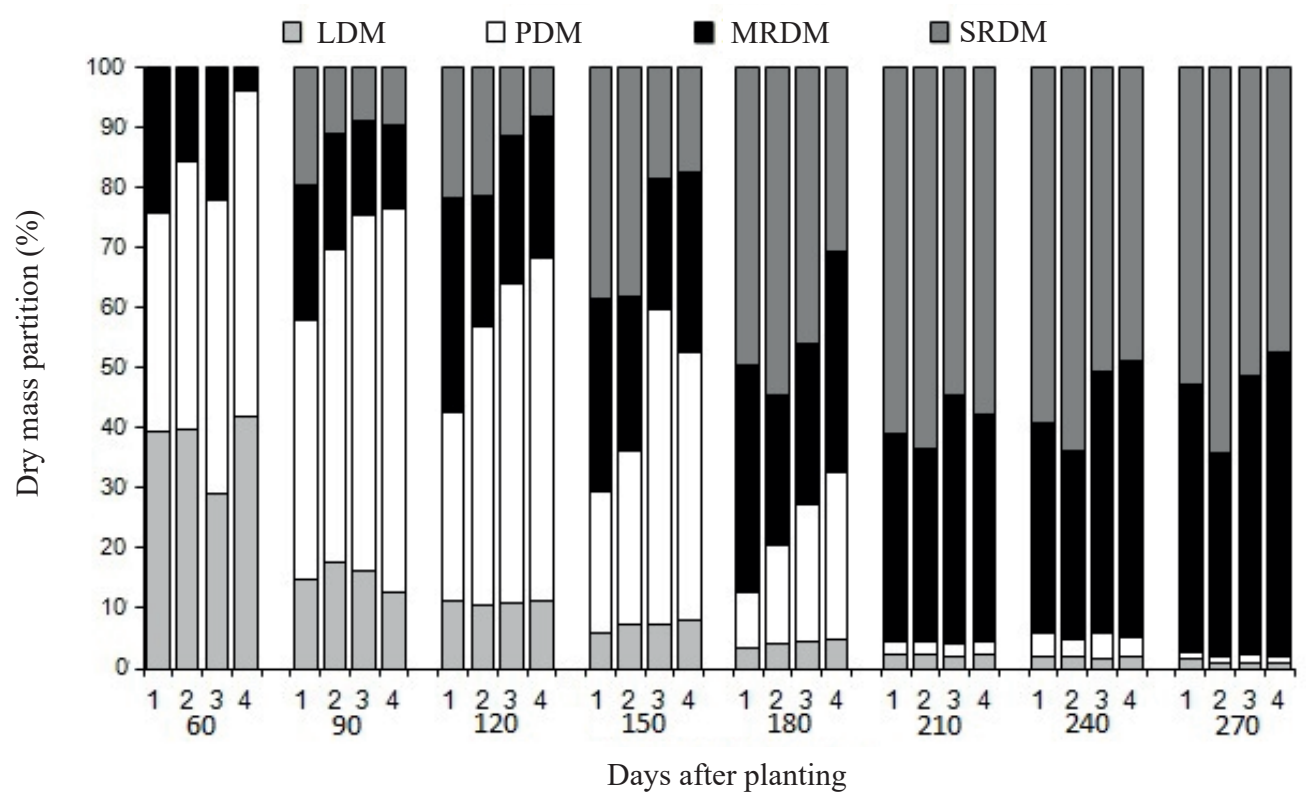

Figure 2. Dry mass partition of 'Japanese' taro plants by day of cultivation (60, 90, 120, 150, 180, 210,240 and 270 days after planting), subjected to artificial shading at distinct periods $(1,2,3$ and 4 are the control and $18 \%, 30 \%$ and $50 \%$ the shading treatments). LDM: leaf dry mass; PDM: petiole dry mass; MRDM: mother-rhizome dry mass; SRDM: son-rhizome dry mass. 
accumulation of $53 \%, 64 \%, 51 \%$ and $47 \%$ of the total dry mass for the control, and $18 \%, 30 \%$ and $50 \%$ of shading, respectively.

At the initial phase, the mass allocation was higher at the leaves, including the treatments with higher shading level. In the later phase, a greater allocation of assimilates to the reserve organs was observed. Zárate et al. (2009) also verified that, after 210 DAP, the son-rhizomes had more than $50 \%$ of assimilated partition. These results are of particular importance to obtain a high productivity intercropping system.

\section{CONCLUSIONS}

1. Shading levels increase the leaf area, specific leaf area, leaf area ratio and leaf mass ratio. Thus, taro plants can make leaf adjustments to suit changes in light intensity;

2. The shading intensity of $18 \%$, with shading during all the cycle or just during a period, leads to a high leaf area expansion.

\section{REFERENCES}

BARRELLA, T. P. et al. Production and mass partitioning in Peruvian carrot plants grown under artificial shading period and intensity. Acta Scientiarum Agronomy, v. 33, n. 2, p. 321-326, 2011.

BEZERRA, A. A. C. et al. Características de dossel e de rendimento em feijão-caupi ereto em diferentes densidades populacionais. Pesquisa Agropecuária Brasileira, v. 44, n. 10, p. 1239-1245, 2009.

CAVATTE, P. C. et al. Germinação e vigor de sementes de cenoura em solo de mineração de calcário sob diferentes intensidades luminosas e adubações. Idesia, v. 27, n. 2, p. 25-32, 2009.

FERREIRA, D. F. Análises estatísticas por meio do Sisvar (sistema para análise de variância) para Windows, versão 4.0. In: REUNIÃO ANUAL DA REGIÃO BRASILEIRA DA SOCIEDADE INTERNACIONAL DE BIOMETRIA, 45., São Carlos, 2000. Anais... São Carlos: Universidade Federal de São Carlos, 2000. p. 255-258.

GONDIM, A. R. O. et al. Crescimento, partição de fotoassimilados e produção de rizomas de taro cultivado sob sombreamento artificial. Horticultura Brasileira, v. 25, n. 3, p. 418-428, 2007.

GONDIM, A. R. O. et al. Plasticidade anatômica da folha de taro cultivado sob diferentes condições de sombreamento. Bragantia, v. 67, n. 4, p. 1037-1045, 2008.

LENHARD, N. R. et al. Crescimento de mudas de pauferro sob diferentes níveis de sombreamento. Pesquisa Agropecuária Tropical, v. 43, n. 2, p. 178-186, 2013.

MONIM, M. A. et al. Effect of intercropping different vegetables with groundnut. Journal of Agroforestry and Environment, v. 4, n. 1, p. 27-30, 2010.

MOTA, C. S. et al. Comportamento vegetativo e produtivo de videiras 'cabernet sauvignon' cultivadas sob cobertura plástica. Revista Brasileira de Fruticultura, v. 30, n. 1, p. 148-153, 2008.

OLIVEIRA, F. L. et al. Crescimento e acumulação de nutrientes em plantas de taro sob níveis de sombreamento artificial. Horticultura Brasileira, v. 29, n. 3, p. 291-298, 2011.

OLIVEIRA, F. L. et al. Desempenho de taro em função de doses de cama de aviário, sob sistema orgânico de produção. Horticultura Brasileira, v. 26, n. 2, p.149-153, 2008.

OLIVEIRA, P. N. et al. Morphological plasticity of benghal dayflower under an artificial light gradient. Acta Scientiarum Agronomy, v. 36, n. 1, p. 51-56, 2014.

PEREIRA, F. H. F. et al. Produção de biomassa e rizomas e incidência de metsubure em taro submetido a doses de potássio com e sem adição de cálcio. Horticultura Brasileira, v. 24, n. 1, p. 7-21, 2006.

RADIN, B. et al. Crescimento de cultivares de alface conduzida em estufa e a campo. Horticultura Brasileira, v. 22, n. 2, p. 178-181, 2004.

SANTOS, L. A. et al. Crescimento, índices fisiológicos e produtividade de cultivares de feijoeiro sob diferentes níveis de adubação. Revista Ceres, v. 62, n. 1, p. 107-116, 2015.

SILVA, M. L. S. et al. Desenvolvimento de mudas de maracujazeiro (Passiflora edulis Sims f. flavicarpa Deg.) sob diferentes níveis de sombreamento. Acta Scientiarum Agronomy, v. 28, n. 4, p. 513-521, 2006.

TEIXEIRA, G. C. S. et al. Eficiência do uso da radiação solar e índices morfofisiológicos em cultivares de feijoeiro. Pesquisa Agropecuária Tropical, v. 45, n. 1, p. 9-17, 2015.

VIEIRA, J. C. B. et al. Viabilidade agroeconômica da consorciação do taro com feijão-vagem indeterminado em razão da época de plantio. Revista Ceres, v. 61, n. 2, p. 229-233, 2014.

ZÁRATE, N. A. Produção e renda bruta de quatro clones de taro cultivados em Dourados, estado do Mato Grosso do Sul. Acta Scientiarum Agronomy, v. 31, n. 2, p. 301305, 2009. 